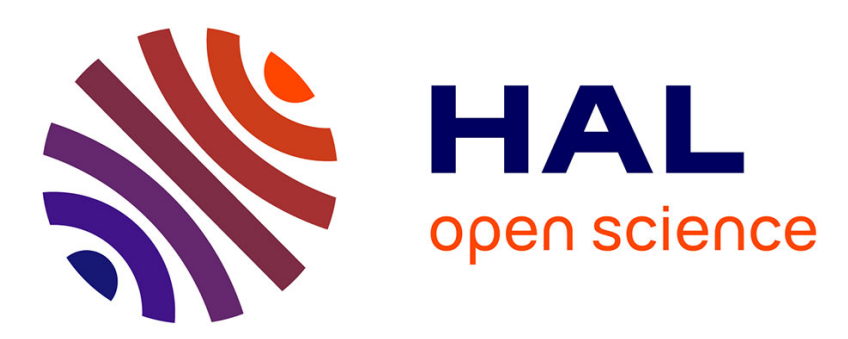

\title{
PLM and BIM approach to support information management in nuclear decommissioning: a synthesis
}

\author{
Vincent Cheutet, Aicha Sekhari, Nathalie Corbeaux
}

\section{To cite this version:}

Vincent Cheutet, Aicha Sekhari, Nathalie Corbeaux. PLM and BIM approach to support information management in nuclear decommissioning: a synthesis. 15th IFIP International Conference on Product Lifecycle Management (PLM 2018), Jul 2018, Turin, Italy. pp.104-114. hal-01847842

\section{HAL Id: hal-01847842 \\ https://hal.science/hal-01847842}

Submitted on 12 Dec 2018

HAL is a multi-disciplinary open access archive for the deposit and dissemination of scientific research documents, whether they are published or not. The documents may come from teaching and research institutions in France or abroad, or from public or private research centers.
L'archive ouverte pluridisciplinaire HAL, est destinée au dépôt et à la diffusion de documents scientifiques de niveau recherche, publiés ou non, émanant des établissements d'enseignement et de recherche français ou étrangers, des laboratoires publics ou privés.

\section{(ㄷ)(1)}

Distributed under a Creative Commons Attribution| 4.0 International License 


\title{
PLM and BIM approach to support information management in nuclear decommissioning: a synthesis
}

\author{
Vincent CHEUTET ${ }^{1}$, Aicha SEKHARI ${ }^{2}$, Nathalie CORBEAUX ${ }^{3}$, \\ 1: University Lyon, INSA Lyon, DISP laboratory EA4570, Villeurbanne FRANCE \\ 2: University Lyon, Université Lumière Lyon 2, DISP laboratory EA4570, Bron FRANCE \\ 3: EDF-DP2D, Lyon FRANCE \\ vincent.cheuteteinsa-lyon.fr \\ aicha.sekhari@univ-lyon2. fr \\ nathalie.corbeauxdedf. fr
}

\begin{abstract}
Nuclear decommissioning is a huge disaster and cumbersome mechanism to handle, after critical analysis and rigorous review it is found that PLM and BIM approaches seem interesting in this field to support the business needs in terms of collaboration, information exchange and traceability all over the decommissioning process. This paper analyses the scientific and industrial literature to extract the requirements for the deployment of a mixed BIM-PLM approach in the nuclear decommissioning context.
\end{abstract}

Keywords: information management, PLM, BIM, nuclear decommissioning

\section{Introduction}

At this time, the first generation of Nuclear Power Plants (NPPs) is gradually being taken out of service and decommissioned. Around 300 nuclear facilities will be stopped around the world in the next 20 years and more than 10 decommissioning operations are on-going in France. A decommissioning process is long, complex and requires the determination and the description of the decommissioning scenario of the installation, which means the description of all the operations which are run from the final shutdown of the NPP units.

Amount of data are needed to establish a physical and radiological inventory of the totality of the NPP [1]. The main challenge is to ensure the access to the right information at the right time to the right person, in order to provide a consistent basis to the decision support framework. Such information must be well storage, managed and controlled, meaning that the user has to be aware of the level of maturity and uncertainty attached to such information to complete our mastery of nuclear-based energy all along its lifecycle. In order to efficiently support, manage and control such activities, information management is so of prior interest.

adfa, p. 1, 2018.

(c) Springer-Verlag Berlin Heidelberg 2018 
Nevertheless, the intrinsic characteristics of Nuclear Facilities Decommissioning (NFD) process make this information management very complex and requires new approaches. In this research work, the authors aim to precisely characterize the NFD process in order to specify the key characteristics that a dedicated information system should gather in order to successfully support the activity. Based on this analysis, the authors compare some promising approaches in information management and information systems by proposing a digital roadmap for NFD information management.

The paper is structured as follows. Chapter 2 characterizes the NFD process and the information generated and required to support this process. Chapter 3 defines the objectives two promising approaches with these key characteristics: PLM (Product Lifecycle Management) and BIM (Building Information Management). Chapter 4 synthesizes the comparison between these two concepts. Chapter 5 analyses their appropriation in the context of NFD and opens new research perspectives.

\section{Information management for nuclear decommissioning}

\subsection{NFD process characteristics}

IAEA (International Atomic Energy Agency) proposes this definition for decommissioning process: "The administrative and technical actions taken to allow the removal of some or all of the regulatory controls from a facility" [2]. It implies that decommissioning does not restrain to the dismantling activities and covers all operations from the preparation to the final site clean-up (Figure 1). In particular, it begins before the end of nuclear operations.

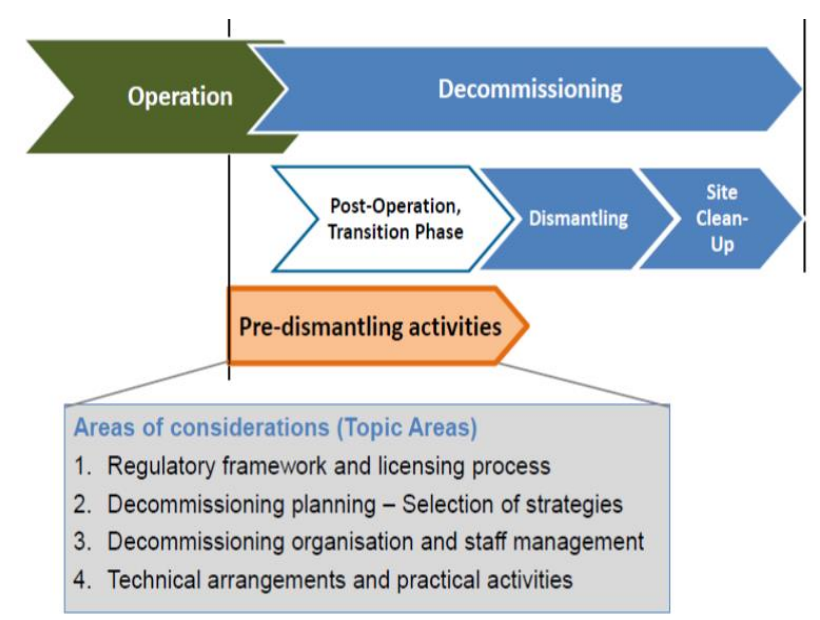

Fig. 1. IAEA definition of nuclear facility decommissioning [3]

A nuclear facility can be seen as a complex system with a very long lifetime. The ones that are currently decommissioned in France were put into service in the 1960s. Even if the first decommissioning activities have finished in the recent years, there is 
still very few experience and feedback on these activities that can be shared among the nuclear community. Moreover, even if it exists some classification of nuclear facilities, their very long operation time and the diversity of needs at their design period imply that there is very few standardisation between nuclear facilities: each of them can be seen as a unique complex system with its particular history. It makes the reusability of information and knowledge more complex for the community. As a consequence, NFD can be considered as project-based, with a perspective of standardisation.

Decommissioning process is also a long-time activity. In France, for PWR (Pressurized Water Reactor), it may last at least 22 years. This process is highly guided by regulations, for instance in France by ASN (Autorité de Sûreté Nucléaire) that validates the dismantling scenario proposed the decommissioner, authorizes the operations and ensures the information and knowledge capitalization.

A large number of stakeholders are implied in the NFD process, from the NF designer that provides any information (digitalized or not) on the facility, the operators (with a special attention on all maintenance operations realised during the operating phase), the regulation authorities (ASN, ANDRA - Agence Nationale pour la gestion des Déchets RAdioactifs - in France), the decommissioner that is responsible of the dismantling scenario design and operation and all the subcontractors that may take part in some activities overall the process.

\subsection{Information characteristics}

With the characteristics listed in the previous section, one can imagine the complexity that occurs in information management for NFD process. In the NFD process, data and information are focusing on three essential elements: the nuclear facility, nuclear wastes and the decommissioning scenario. The main focus is so on a specific instance of elements that is central to the NFD. Some examples of data and information required by the regulations in the process are: requirements (project, regulatory, functional, technical ...), descriptive documents of the installations, data on hardware, operating history, physical and radioactive inventory, costs, etc. Among others, one can list these specificities that will have a strong impact on data and information management:

- A large number of data and information may not be digital, due to the long lifetime of facilities,

- Data and information are strongly heterogeneous, due to few standardization between facilities, to the large number of stakeholders with very specific expertise,

- Data and information are highly spread over a large number of dedicated and heterogeneous information systems among the stakeholders,

- Data and information are on very different levels of detail, with data on very specific parts or information on all the facility, with possibly 1D, 2D or 3D digital mockup.

- The quality of data and information is untrusty, with problems of redundancy, inconsistency, uncertainties, inaccessibility and unsuitability for end users that occurs. 
Finally, due to the lack of experience and feedback, information management is nonmature at that time and so a strong effort is required to define and share these specifications. With all these constraints and specificities, it is not complicated to understand why there is few research works that have tackled this problem of information management in the context of NFD. Among the literature, one can cite [1], [4] and [5] that have proposed an integrated information systems for NFD but which implantations are still limited, or [6] that focuses on information management for dismantling planning.

In the current research works, the authors analyses the EIS (Enterprise Information Systems) families that have been developed with a different objective [7] to find if an adaptation is possible. Among the listed EIS (Enterprise Resource Planning (ERP), Supply Chain Management (SCM), Manufacturing Execution Systems (MES), Customer Relationship Management (CRM), Product Lifecycle Management (PLM) and Business Intelligence (BI)) with addition of BIM and Enterprise Asset Management [28], two are promising according to their nature: PLM and BIM. In fact they are both by nature project-based, centred on a specific instance of elements and they aim at enhancing the collaboration among a large number of heterogeneous stakeholders. This finding is enhanced by the strategic choices of the Digital Transformation program of our industrial partner (EDF).

\section{$3 \quad$ PLM-BIM definitions and objectives}

PLM can be mostly understood as the information backbone of the organization attached to the all lifecycle of a product. The Product Lifecycle Management (PLM) concept holds to integrate all the information produced throughout all phases of a product's life cycle to everyone in an organization at every managerial and technical level, along with key suppliers and customers [8]. The lifecycle model consists of three phases during which information must be tracked and knowledge capitalized: The Beginning-ofLife (BOL), the Middle-of-Life (MOL) and finally, the End-of-Life (EOL). PLM tools are based on technologies such as the Cloud and SOA architecture, and integrate functionalities to enhance collaboration, workflow engine to automate processes, approaches to manage product variants and versions, PLM is supposed to fill the gap between enterprise business processes and product development processes. In other terms, PLM works as glue which adhere all the processes that have something to do with product and connects all functional silos to make them horizontally integrated [9].

BIM is defined as the method of generation execution and monitoring of the "building data" during its life process. Moreover, BIM is also known as a combination of process and technology to improve efficiency and effectiveness of delivering a project from inception to operation and maintenance [10]. In construction projects, BIM has been used by architecture, engineering and construction or facilities management (AEC/FM) to implement collaborative management of construction projects between all stakeholders. The term generally refers both the model(s) representing the physical characteristics of the project and to all the information contained in and attached to the component of theses model [11]. As a clear and practical example, while a door represented in a 2D CAD drawing is just a collection of lines, in BIM it is an intelligent 
object containing information on its size, cost, manufacturer, schedule and more. According to [12], BIM should be used as a building model repository. A building model repository is a database system whose schema is based on a published object based format. It is different from existing project data management (PDM) systems and webbased project management systems in that the PDM systems are file based, and carry $\mathrm{CAD}$ and analysis package project files. Building Model repositories are object based, allowing query, transfer, updating and management of individual project objects from potentially heterogeneous set of application.

While BIM has existed for some time, advances in information and communication technologies (ICTs) have strongly encouraged the adoption of the concept. Recently, BIM has attracted the market demand from engineering, designing, building and warehousing domains. It creates and manages huge landscape of opportunities by associating with like-minded and in-lined areas and processes. In [10], they state that BIM is a process that brings all data or information on project design together in one parametric model giving benefits to construction projects in terms of time, cost and quality and helps design team to solve the design clashes early in pre-construction stage. As a summary, BIM consists of at least three dimensions: process, technology and people. The findings from the literature revealed some barriers and challenges in BIM implementations. In an NBS report [13], 67\% of BIM users and 64\% of non-BIM users confirmed cost was a major barrier to BIM uptake. The same sources revealed that the lack of knowledge about different BIM software packages is a major barrier to their adoption. Up-to-now, very few works focus on BIM implementation for end-of-life activities and one can cite [27] that elicits the essential functionalities for a BIM-based deconstruction tool in the context of classical facilities.

The focus on entire aspect of BIM exemplifies its close proximity to PLM. The evolution of BIM, and its analogy with PLM provides a platform to expand current knowledge of these ideas, introduce new fields of research, and develop innovative scientific information domains. The following paragraph deals with a comparative study between PLM and BIM.

\section{PLM-BIM comparative study}

When looking to PLM and BIM, many sharing concepts come in play. They take into consideration the entire vision of effectively managing and connecting all information related to the Process, People, Data and integration of this information to other business systems across the entire lifecycle of the products companies manufacture or construction industry. PLM and BIM are not just technology, but an approach in which processes are as important as data. Similarities between the two approaches are creation, integration and reuse of project information, the concept of 'digital mock-up' and project management practices. PLM and BIM both have same common objective, i.e. to increase collaboration, productivity, optimization, and to deliver better value to the client. Inter-relations between BIM and PLM have already been addressed in previous works. But the subject is still very interesting and it is not always easy to clarify what is the role and advantages of each of them and how they can accept each other. 
There are only a few documented efforts on PLM and BIM integration benefit. One of the main gaps identified in the literature relates to the lack of research sur-rounding the role of PLM in the BIM methodology [15]. Few works that consider the research on the implementing of PLM systems in the AEC companies.

These previous research work has shown that it is possible to improve BIM with the features and the best practices from Product Lifecycle Management (PLM) approach [26]. Authors of [16] identified the BIM management requirements that reflect core PLM functions, including data organization, version management, release management and role/responsibility identification. Authors of [15] analysed the consequences of incomplete BIM implementation. The study identified three types of problems: processbased issues, technology based issues and policy-based issues. The results are that PLM can actually be an opportunity to expand existing applications of BIM. However the study also suggests that the transverse application of a BIM-PLM solution that is based on discrete manufacturing processes might lead to other types of problems due to the complexity of interfaces observed in construction projects [26].

To summarize, BIM and PLM share a number of similarities relative to their approach to data sharing, project management, organization of teams around deliverables and timelines, and object-based visualization activities [14].

At the same time, the literature count a number of key differences between BIM and PLM concepts and their practical deployment. These differences can be seen to stem from the different structures, backgrounds and traditions of their respective industries. BIM has amazing features to manage the different process of the building from design to construction but lacks the monitoring and management mechanism, and this the main point where both PLM and BIM are discriminated. PLM offers the strong management capabilities for the lifecycle of the any constructed project. Using the BIM we can know the state of building at present time whereas with PLM it is possible to know what were the modifications made at such moment and thus to know what was the condition of building at some point in the past. Besides, there is lack of BIM standards for model integration and is being managed by multidisciplinary teams. Integrating multidisciplinary information in a single BIM model requires multiuser access to the BIM model. At the moment, since there are no standard protocols available, each firm adopts its own standards. This could create inconsistencies in the model, which if not properly detected, could lead to inaccurate and inconsistent BIM model. The exclusion of PLM's activities in the deployment of the BIM methodology can lead to failures in presenting the merits of BIM to tasks and lessen its importance to customers:

On one hand, we have BIM, a unique data model that allows the collaboration of the different actors and focuses mainly on the visualization functions, the calculations of the properties, and the verification of the interactions between the different elements of the digital model. But which does not deal with document management or the control of reports and versions of documents. On the other hand, we have the PLM which allows the management of the lifecycle of the construction project and formalizes the processes of modification, validation, exchange.

As a conclusion, it can be claimed that BIM is a subset of PLM and major part of any organization is based on the accurate management and the monitoring of the assets. As addressed by the national BIM standard project committee that BIM is a digital 
representation of physical and functional characteristics of a facility, besides it is a shared knowledge resource for information about a facility forming a reliable basis for decisions during its lifecycle; defined as existing from earliest conception to demolition. PLM is an integrated, information-driven approach to all aspects of a product's life from its design inception through its manufacture, deployment and maintenance, culminating in its removal from service and final disposal. Table 1 proposes a synthetic comparison of PLM and BIM approach.

Table 1. Comparisons between BIM and PLM

\begin{tabular}{|c|c|c|}
\hline & PLM & BIM \\
\hline $\begin{array}{l}\text { Infor- } \\
\text { mation } \\
\text { manage- } \\
\text { ment }\end{array}$ & $\begin{array}{l}\text {-Data retrieved from various models } \\
\text { are managed and stored in vault. } \\
\text {-Data exchange standards have of- } \\
\text { ten been criticized for their inability to } \\
\text { capture well-defined business pro- } \\
\text { cesses, work flow patterns/ systems, } \\
\text { and underlying business rules. } \\
\text {-Capabilities of PLM system have } \\
\text { been enhanced to capture, manage and } \\
\text { preserve the created information for } \\
\text { the entire product portfolio of a } \\
\text { company }\end{array}$ & $\begin{array}{l}\text {-It does not distinguish between re- } \\
\text { quirements, functional and physical } \\
\text { documents. } \\
\text {-The information maintained and pro- } \\
\text { duced in the BIM approach includes } \\
\text { both the geometric and non-geometric } \\
\text { data. } \\
\text {-Limited to single project or prod- } \\
\text { uct. }\end{array}$ \\
\hline $\begin{array}{l}\text { Ap- } \\
\text { proach }\end{array}$ & $\begin{array}{l}\text {-Product-driven PLM paradigm } \\
\text {-REX - The focus is instead on the } \\
\text { overall business process } \\
\text {-With PLM, companies think of the } \\
\text { standard processes, standard data and } \\
\text { standard systems that they, and the nu- } \\
\text { merous suppliers, customers, and part- } \\
\text { ners, can use to save an enormous } \\
\text { amount of time and money } \\
\text {-PLM implementation team work } \\
\text { closely with the cross-functional } \\
\text { business teams. }\end{array}$ & $\begin{array}{l}\text {-Technology led BIM paradigm } \\
\text {-BIM is an interdependent network of } \\
\text { processes, technologies and policies, } \\
\text { which constitutes a 'methodology to } \\
\text { manage building design and project } \\
\text { data in digital format throughout the } \\
\text { building's lifecycle' } \\
\text {-Rules and requirements have not } \\
\text { yet been developed nor established } \\
\text { within current BIM approaches. } \\
\text {-BIM emphasizes open communica- } \\
\text { tion and information exchange, col- } \\
\text { laborative decision making, early par- } \\
\text { ticipation and contribution of } \\
\text { knowledge and expertise by down- } \\
\text { stream stakeholders (contractors and } \\
\text { suppliers), and greater levels of risk } \\
\text { sharing }\end{array}$ \\
\hline Domain & $\begin{array}{l}\text {-PLM in the manufacturing sectors is } \\
\text { more established } \\
\text { In the construction sector, BIM is still } \\
\text { considered a recent concept and } \\
\text { should therefore benefit from the les- } \\
\text { sons of PLM implementation. }\end{array}$ & $\begin{array}{l}\text {-Construction industry is still in the } \\
\text { early phases of BIM adoption } \\
\text { In the construction sector, BIM is still } \\
\text { considered a recent concept and } \\
\text { should therefore benefit from the les- } \\
\text { sons of PLM implementation. }\end{array}$ \\
\hline
\end{tabular}




\section{$5 \quad$ PLM-BIM in nuclear facilities and perspectives}

With this perspective, we can analyse how these two approaches have been deployed in nuclear facilities context. PLM and BIM are considered as important collaborative approach in delivering a safe, secure and cost effective nuclear as well as other emerging domains or example, construction, manufacturing and architectural platform [17].

A large literature exists on the deployment of PLM and/or BIM to support the BOL (Beginning of Life) or MOL (Middle of Life) phases of NPPs [18-20]. One can cite for instance [18] that address the digitized concept of the nuclear industries by deploying PLM and BIM merely focusing on the UK's nuclear sector. In their discussion, they all claim that both PLM and BIM play the remarkable role in the manufacturing and constructing the innovative NPP and industries.

Some authors are enlarging the scope of BIM and/or PLM to tackle the entire NPP lifecycle [21-24]. As an example, authors of [24] examine that one of the critical challenges while keeping the foundation of NPP from set-up to decommission phase is the proper and accurate management of the resources in the short span of time. Besides, most of the societal needs are inter-related to the efficient utilization of the power plants due to various hurdles and expenses to tackle, so PLM is the dire need of the overall nuclear facility environment.

Nevertheless, none of these works are properly tackling the specificities of NFD and only consider this process as part of EOL (End-of-Life) phase of NPP lifecycle. In our understanding of these concepts, applying them specifically to this process can improve the overall performance and safety.

In this research works, we extensively synthesize the leading role of both BIM and PLM on the basis of their significant contribution in the NFD process. After deep analysis and critical examination of the literature, a list of functionalities that are required for NFD can be drawn (Figure 2), with PLM specific ones, BIM specific ones, BIMPLM common ones and NFD specific one that does not exist at that moment neither in BIM nor PLM.

In perspective, if BIM and PLM are definitively interesting approach to support NFD process, some questions remain open, among them: what is the "Product" in this approach? A model mixing the plant, the wastes and the dismantling scenarios in the product concept is being experimented in [25], with configuration management as key characteristics to handle the diversity of products and lifecycle.

\section{References}

1. Chou I.H., Fan C.F. (2006). Developing integrated decommissioning information management system (IDIMS) of nuclear facilities. Journal of Nuclear Science and Technology, 43(5):596-604, https://doi.org/10.1080/18811248.2006.9711138

2. IAEA (2005). Standard format and content for safety related decommissioning documents. International Atomic Energy Agency, Safety Reports Series No. 45

3. Michal V. (2016). IAEA perspectives on preparation for decommissioning. In International Symposium on Preparation for Decommissioning - PREDEC'16, Lyon, France. 


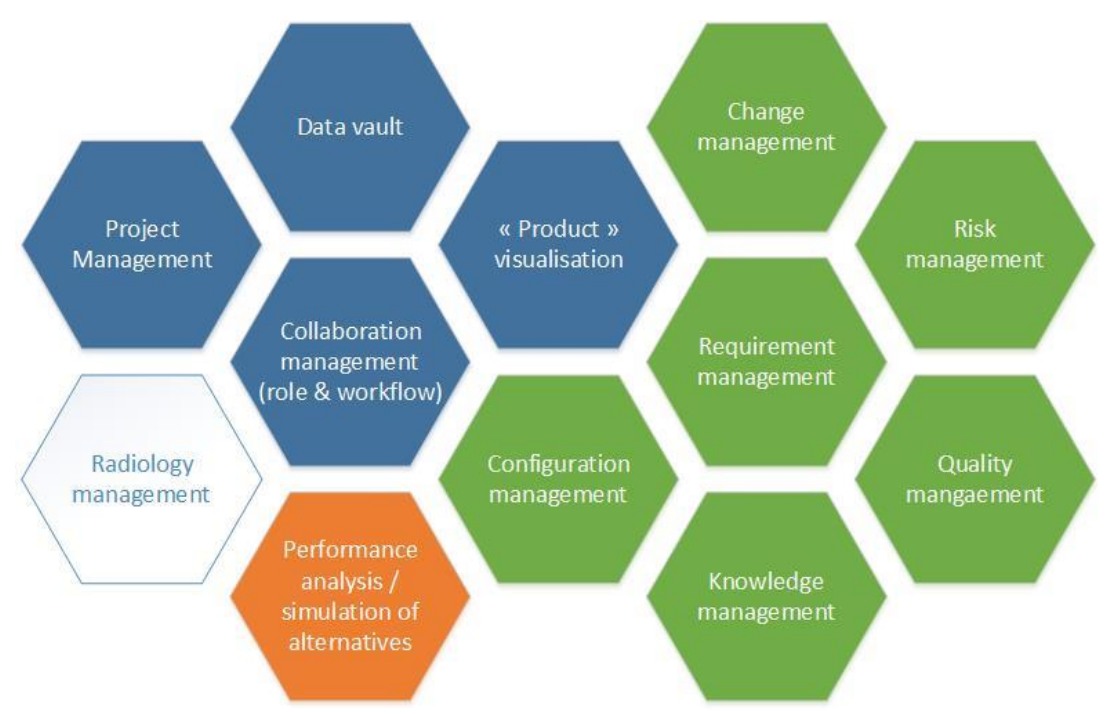

Fig. 2. BIM-PLM functionalities elicited for NFD: in green PLM-specific functionalities, in red BIM-specific ones, in blue BIM-PLM common ones and in white NFD-specific one.

4. Leclair A.N., Lemire D.S. (2012) 26 - Information management for nuclear decommissioning projects. In Woodhead Publishing Series in Energy, edited by Michele Laraia, Woodhead Publishing (pp. 777-798), Nuclear Decommissioning

5. Iguchi Y., Kanehira Y., Tachibana M., Johnsen T. (2004) Development of Decommissioning Engineering Support System (DEXUS) of the Fugen Nuclear Power Station. Journal of Nuclear Science and Technology, 41(3):367-375, https://doi.org/10.1080/18811248.2004.9715497

6. Yanagihara S., Sukegawa T., Shiraishi K. (2001). Development of computer systems for planning and management of reactor decommissioning. Journal of Nuclear Science and Technology, 38(3):193-202, https://doi.org/10.1080/18811248.2001.9715021

7. Romero D., Vernadat F. (2016). Enterprise information systems state of the art: past, present and future trends. Computers in Industry, 79:3-13, https://doi.org/10.1016/j.compind.2016.03.001

8. Sudarsan R., Fenves S.J., Sriram R.D., Wang F. (2005). A product information modeling framework for product lifecycle management. Computer-Aided Design, 37(13):1399-1411, https://doi.org/10.1016/j.cad.2005.02.010

9. Ameri F., Dutta D. (2004). Product lifecycle management needs, concepts and components. Product Lifecycle Management Development Consortium.

10. Latiffi A.A., Mohd S., Rakiman U.S. (2015). Potential improvement of Building Information Modeling (BIM) implementation in Malaysian construction projects. In IFIP International Conference on Product Lifecycle Management (pp. 149-158). Springer, Cham, https://doi.org/10.1007/978-3-319-33111-9_14

11. Haron A.T., Marshall-Ponting A.J., Aouad G. (2009). Building Information Modelling in integrated practice. 2nd Construction Industry Research Achievement International Conference. Kuala Lumpur, Malaysia

12. Eastman C.M., Eastman C., Teicholz P., Sacks R. (2011). BIM handbook: A guide to building information modeling for owners, managers, designers, engineers and contractors. John Wiley \& Sons. 
13. NBS (2014). NBS National BIM Report 2014. Available at https://www.thenbs.com/knowledge/nbs-national-bim-report-2014

14. Jupp J.R., Nepal M. (2014). BIM and PLM: comparing and learning from changes to professional practice across sectors. In IFIP International Conference on Product Lifecycle Management (pp. 41-50). Springer, Berlin, Heidelberg, https://doi.org/10.1007/978-3-662-45937-9 5

15. Jupp J.R. (2013). Incomplete BIM implementation: Exploring challenges and the role of product lifecycle management functions. In IFIP International Conference on Product Lifecycle Management (pp. 630-640). Springer, Berlin, Heidelberg, https://doi.org/10.1007/978-3-64241501-2_62

16. London K., Singh V., Taylor C., Gu N., Brankovic L. (2008). Building information modelling project decision support framework. In Proceedings of the Twenty-Fourth Annual Conference Association of Researchers in Construction Management (ARCOM).

17. Aram S., Eastman, C. (2013). Integration of PLM solutions and BIM systems for the AEC industry. In Proceedings of 30th International Symposium of Automation and Robotics in Construction and Mining, Montréal (pp. 1046-1055).

18. Walker A. (2016). Big benefits for nuclear sector by going digital Building Information Modelling (BIM) and Project Lifecycle Management are transforming the nuclear industry for lifecycle value and assurance. http://www.infrastructure-intelligence.com/article/apr2016/big-benefits-nuclear-sector-going-digital

19. Yalcinkaya M., Singh V. (2014). Building information modeling (BIM) for facilities management-literature review and future needs. In IFIP International Conference on Product Lifecycle Management (pp. 1-10). Springer, Berlin, Heidelberg, https://doi.org/10.1007/978-3-66245937-9_1

20. Tommila T., Alanen J. (2015). Conceptual model for safety requirements specification and management in nuclear power plants. VTT-VTT Technology, 238, 120.

21. Cronin B. (2015). BIM in Nuclear Decommissioning, https://thebimhub.com/2015/04/06/bim-in-nuclear-decommissioning/\#.WqvfG2rOW71

22. Pottelberg P., Tremblay R. (2016). The Turnover Process at Chalk River Laboratories from Operations to Decommissioning. PREDEC 2016 conference, Lyon (France)

23. Calais T., Rauber J.C. (2016). Control and maintenance of the Superphenix knowledge and its specific sodium skills through an innovative partnership between EDF and AREVA, PREDEC 2016 conference, Lyon (France).

24. IAEA-TECDOC-1305 (2002), Safe and effective nuclear power plant life cycle management towards decommissioning, 1-36.

25. Cheutet V., Sekhari A., Corbeaux N. (2018). A PLM approach to support nuclear decommissioning process. In DEM 2018 - Dismantling Challenges: Industrial Reality, Prospects and Feedback Experience, Avignon (France).

26. Boton C., Rivest L., Forgues D., Jupp J. (2016). Comparing PLM and BIM from the product structure standpoint. In IFIP International Conference on Product Lifecycle Management (pp. 443-453). Springer, Cham, https://doi.org/10.1007/978-3-319-54660-5_40

27. Akinade O.O., Oyedele L.O., Omoteso K., Ajayi S.O., Bilal M., Owolabi H.A., Alaka H.A., Ayris L., Looney J.H. (2017). BIM-based deconstruction tool: Towards essential functionalities. International Journal of Sustainable Built Environment, 6(1), 260-271, https://doi.org/10.1016/j.ijsbe.2017.01.002

28. Kraft D., Francisco W. (2016). Establishing a governance framework to provide leadership to a new enterprise asset management program. In Asset Management Conference (AM 2016), https://doi.org/10.1049/cp.2016.1403 